\title{
QUALITATIVE CHANGES AND DYNAMICS \\ OF PROTEIN SYNTHESIS DURING COLD AND WARM STRATIFICATION OF NORWAY MAPLE (ACER PLATANOIDES L.) SEEDS
}

\author{
TOMASZ PAWŁOWSKI, ZOFIA SZCZOTKA AND KAZIMIERZ KRAWIARZ \\ Institute of Dendrology, Polish Academy of Science, \\ 62-035 Kórnik, ul. Parkowa 5, Poland
}

(Received: August 28, 1996. Accepted: August 12, 1997)

\begin{abstract}
Protein synthesis in cotyledons and embryo axes of Norway maple (Acer platanoides L.) was studied in seeds stratified at 3 or $15^{\circ} \mathrm{C}$. At $3^{\circ} \mathrm{C}$ stratification, germination of seeds starts after 9 weeks, at $15^{\circ} \mathrm{C}$ stratification germination does not occur. The changes of protein synthesis level in both temperatures had two phasic character. In embryo axes $\left(3\right.$ and $\left.15^{\circ} \mathrm{C}\right)$ protein synthesis grow up, but in cotyledons $\left(3^{\circ} \mathrm{C}\right)$ synthesis of proteins decrease. Generally, activity of protein synthesis was higher at $3^{\circ} \mathrm{C}$, as like as DNA level was higher. After imbibition, in cold and warm stratification, in embryo axes, many new protein are become visible. We expect, that two from this proteins, determined as A and B my be connected with the releasing from dormancy. In seeds stratified at $15^{\circ} \mathrm{C}$, these proteins are occuring in vestigal amount or are completely absent.
\end{abstract}

KEY WORDS: Acer platanoides, dormancy breaking, DNA, proteins, seeds.

\section{INTRODUCTION}

After reaching maturity seeds of many trees enter the state of deep dormancy. Their germination requires cold stratification. This group of seeds includes Norway maple. They need approximately 16 weeks of cold stratification $\left(3-4^{\circ} \mathrm{C}\right)$ to emerge from deep dormancy and start germinating.

Little is know of the molecular basis of controlling dormancy in tree seeds. Current theories include mechanisms mediated by endogenous growth regulators or by changes in relative concentration of different growth regulators (Tomaszewska 1976, Ross and Bradbeer 1971, Khan 1982) and quantities and qualitatives as effect of gene expression (Slater and Bryant 1987).

Therefore, researches consider the changes in the dynamics of protein synthesis (Szczotka and Tomaszewska 1979, Davies and Pinfield 1987) and the qualitative differences in the composition of proteins (Hance and Bevington 1992) to be important in the breaking of dormancy. They observed the qualitative differences between proteins related to the stratification of Sugar maple.

According to Slater and Bryant (1987) during stratification of maple seeds there is an increase in the content of the RNA accompanied by growing number of ribosomes. Our earlier research (Szczotka and Konieczny 1979) showed that during cold stratification of maple seeds there is an increase in the fraction of polisomes at the expense of monosomes.

Results of studies carried out in our laboratory (Szczotka and Tomaszewska 1979) point to the phasic nature of changes of numerous metabolic indicators including protein synthesis and the activity of the elongation factor 1 (Korcz et al. 1986).
In our opinion this could be a result of gradual genome derepression which in the first phase is related to the imbibition and in the second phase is due to low temperature associated with dormancy breaking. The third phase is related to germination. The gradual genome derepression can be a result of successive changes in biological activity of the basic growth regulators taking place in the seeds under investigation (as discovered by Tomaszewska 1976).

The results presented in this publication form a continuation of the earlier research. If our thesis concerning the phase genome derepression is correct than the next phase of dormancy breaking could be accompanied by the synthesis of qualitatively different proteins and not just changes in the dynamics of protein synthesis accompanied by changes in the transcription activity of nuclear chromatin and changes in DNA content.

\section{MATERIALS AND METHODS}

Studies were carried out on maple tree seeds collected in the autumn of 1994 in the Kórnik Arboretum. After collection, the seeds were dried at room temperature until they reached approximately $10 \%$ water content. Such dried seeds were then stored in $-3^{\circ} \mathrm{C}$.

After imbibition ( 48 hours at room temperature) they were subjected to cold $\left(3^{\circ} \mathrm{C}\right)$ or warm $\left(15^{\circ} \mathrm{C}\right)$ stratification.

The analysis was carried out on isolated bud seeds (qualitative protein analysis, transcription activity) and on isolated embryo axes and cotyledons (dynamics of protein synthesis).

Transcription activity was estimated according to Schneider (1983). The organic matter was homogenised in liquid nitro- 
gen with a buffer ( $50 \mathrm{mM}$ TRIS-HCl pH $6.0,20 \mathrm{mM} \mathrm{MgCl}_{2}$, $10 \mathrm{mM}$ 2-mercaptoethanol, $0.6 \mathrm{M}$ sucrose, $20 \mathrm{mM} \mathrm{KCl}, 40 \%$ glycerol). The homogenate was then filtered through 4 layers of gauze and 2 layers of Miracloth filter. The filtrate was centrifuged for 4 minutes at $900 \mathrm{~g}$. The supernatant liquid was treated with $30 \%$ Triton to the final $2 \%$ concentration and then centifuged for $15 \mathrm{~min}$. at $2000 \mathrm{~g}$. The pellet was suspended in a buffer (content as homogenising buffer but enriched with $0.2 \%$ Triton $\times 100$ ) and centrifuged for $5 \mathrm{~min}$. at 12000 g. After centrifugation the pellet was suspended in the same buffer and recentrifuged. The pellet was rinsed twice with a buffer (50 mM TRIS-HCl pH 8.0, 2 mM MgCl, $1 \mathrm{mM}$ 2-mercaptoethanol, $20 \%$ glycerol). Finally the pellet was suspended in a buffer as above. The transcription activity of nucleic chromatine was marked in $0.1 \mathrm{mM}$ of the standard incubation mixture containing $5 \mathrm{ml} 5 \mathrm{mM}$ TRIS- $\mathrm{HCl} \mathrm{pH} 8.0,2 \mathrm{ml} 1 \mathrm{mM}$ $\mathrm{MgCl}_{2}, 5 \mathrm{ml} 20 \mathrm{mM} \mathrm{KCl}, 2 \mathrm{ml} 1 \mathrm{mM}$ 2-mercaptoethanol, $3 \mathrm{x}$ $10 \mathrm{mM}$ each of the triphosphonucleotides (ATP, GTP, CTP), $0.5 \mathrm{mCi}\left({ }^{14} \mathrm{C}\right)$-UTP and $50 \mathrm{ml}$ of chromatine nucleic suspension. After $15 \mathrm{~min}$. incubation at $35^{\circ} \mathrm{C}$ the mixture was placed on 3MM Whatman filter-paper discs and immersed for 10 min. in $10 \%$ trichloroacetic acid (TCA) containing $0.9 \%$ $\mathrm{Na}_{4} \mathrm{P}_{2} \mathrm{O}_{7}$. The discs were rinsed 5 times in $5 \%$ TCA containing $0.9 \% \mathrm{Na}_{4} \mathrm{P}_{2} \mathrm{O}_{7}$ and once in $96 \%$ ethanol. Then they were dried and immersed in toluene scintillator ( $4 \mathrm{~g}$ PPO, $0.1 \mathrm{~g}$ POPOP in 11 toluene). Radioactivity was measured with a scintillator counter. The measure of the transcripting activity was the introduction of radioactive ${ }^{14} \mathrm{C}$-UTP to the product which was not soluble in acid.

The DNA content was determined using the Burton method (1965). To $50 \mathrm{ml}$ of the nucleic preparation $950 \mathrm{ml} \mathrm{\textrm {HClO } _ { 4 }}$ was added. The suspension was then centrifuged for $10 \mathrm{~min}$. at $6000 \mathrm{~g}$. $1 \mathrm{ml}$ of $0.5 \mathrm{~N} \mathrm{HClO}_{4}$ was added to the pellet which was hydrolysed for $45 \mathrm{~min}$. at $70^{\circ} \mathrm{C}$. After centrifugation for $15 \mathrm{~min}$. at $800 \mathrm{~g}$ at $4^{\circ} \mathrm{C}$ to $0.2 \mathrm{ml}$ of supernatant liquid $0.8 \mathrm{ml}$ of $0.5 \mathrm{~N} \mathrm{HClO}_{4}$ and $2 \mathrm{ml}$ of Dish reagent $(750 \mathrm{mg}$ of diphenyloamine dissolved in $50 \mathrm{ml}$ of acetic acid glacial, $0.75 \mathrm{ml}$ of concentrated $\mathrm{H}_{2} \mathrm{SO}_{4}$ and $0.1 \mathrm{ml}$ of $1.6 \%$ acetaldehyde) was added. The mixure was then incubated for $30 \mathrm{~min}$. at $90^{\circ} \mathrm{C}$. Extinction was measured at $600 \mathrm{~nm}$.

The dynamics of protein synthesis was determined as in the paper by Szczotka 1975. To $1 \mathrm{ml}$ incubation mixture containing a buffer (pH 7.8) consisting of $0.15 \mathrm{mM} \mathrm{NaCl}, 0.05 \mathrm{mM}$ TRIS, $0.025 \mathrm{mM}$ sodium acetate, $20 \mathrm{mg} / \mathrm{ml}$ chloramphenicol, $10 \mathrm{ml}$ of ${ }^{14} \mathrm{C}$-leucine was added $(4 \mathrm{MBq} / 0.5 \mathrm{ml})$.

In $1 \mathrm{ml}$ of the medium $100 \mathrm{mg}$ of freshly dissected embryo axes have been incubated for 24 hours at $15^{\circ} \mathrm{C}$.

After incubation the material was washed with 11 of distilled water and after drying with filter paper it was frozen with liquid nitrogen. The frozen samples were ground dry for 10 min. in a mortar. After the material was finely ground it was given $1 \mathrm{ml}$ of $0.05 \mathrm{M} \mathrm{NaOH}$ solution and ground for further $10 \mathrm{~min}$. After such homogenisation a suspension was obtained sufficiently fine as to eliminate differences in radioactivity caused by uneven fragmentation of different samples. 50 $\mathrm{ml}$ samples of the homogenate were then transferred to $3 \mathrm{MM}$ Whatman filter discs, dried and immersed in a 5\% solution of TCA. Discs containing the samples were oven-heated with $5 \%$ TCA for $15 \mathrm{~min}$. at $95^{\circ} \mathrm{C}$ to eliminate the aminoacids bound in the aminoacyl-tRNA complex. Then the discs were washed successively with 5\% TCA, a mixture of ethanol/ether 1: 1 and ether. After drying with ether the discs were placed in a toluene scintilator, and the radioactivity was measured on a Packard counter.
Two-dimensional electrophoresis (2-DE) was performed by the combination of isoelectric focusing (first dimension) and SDS - PAGE (second dimension) as developed by Klose (1983). The IEF gels contained 4\% w/v carrier ampholytes WITAlytes pH 2-11 (WITA, Teltow, Germany). The protein sample was applied to the anodic side at the gel and focused. After IEF, gels were equilibrated for $10 \mathrm{~min}$ in buffer containing $125 \mathrm{mM}$ TRIS-phosphate $\mathrm{pH} 6.8,40 \%$ glycerol, $70 \mathrm{mM}$ DTT, and 3\% SDS. The IEF gel was applied onto the SDS PAGE gel, containing $15 \% \mathrm{w} / \mathrm{v}$ acrylamide and $0.4 \%$ bisacrylamide. The SDS - PAGE system of Laemmli (1970) was used. The proteins were stained by silver staining according to Heukeshoven and Dernick (1985).

Protein preparation for 2-DE. For each extract $2 \mathrm{~g}$ embryo axes were homogenized in liquid nitrogen in a mortar. The homogenate was thawed in centrifuge tube and solubilized in buffer containing $0.5 \mathrm{M}$ sucrose, $50 \mathrm{mM}$ TRIS-HCl pH 8.0, $50 \mathrm{mM} \mathrm{KCl}, 5 \mathrm{mM}$ magnesium acetate, $10 \mathrm{mM}$ 2-mercaptoethanol, $1 \mathrm{mM}$ PMSF, $0.1 \mu \mathrm{M}$ pepstatin, $2.1 \mu \mathrm{M}$ leupeptin. After centrifugation to supernatant ammonium sulfate was added, and this mixture was dialised in a buffer containing $9 \mathrm{M}$ urea, $25 \mathrm{mM}$ TRIS-HCl pH 7.3, $50 \mathrm{mM} \mathrm{KCl,} 3 \mathrm{mM}$ EDTA, $70 \mathrm{mM}$ DTT and $2 \%$ carrier ampholytes WITAlytes $\mathrm{pH}$ 2-11 (WITA, Teltow, Germany). The resulting protein concentration determined by the Bradford method (1976) was in the $0.5-1.5 \mathrm{mg} / \mathrm{ml}$ range. Up to $10 \mu \mathrm{l}$ of the sample was applied to the isoelectric focusing gel.

The experiment was repeated twice with similar results.

\section{RESULTS}

The seeds subjected to cold stratification $\left(3^{\circ} \mathrm{C}\right)$ start germinating between 5 and 8 weeks and the seeds stratified at $15^{\circ} \mathrm{C}$ failed to germinate and remained in a state of deep dormancy until the end of the experiment.

\section{Protein synthesis}

Until the second week of both cold and warm stratification the level of protein synthesis in embryo axes remained similar and more or less constant (Fig. 1 A). From week 2, however, the synthesis of protein at $3^{\circ} \mathrm{C}$ began growing steadily (exept week 8). This was similar to the results published earlier (Szczotka and Tomaszewska 1979). As far as the activity of protein synthesis at $15^{\circ} \mathrm{C}$ since week 2 is concerned it decreases reaching the lowest level in weeks 5 and 6 and then starts growing until the end of the experiment (week 11). Generally, the intensity of protein synthesis in embryo axes is much higher under the condition of cold stratification.

The incorporation of ${ }^{14} \mathrm{C}$ leucine into cotyledons (Fig. 1b) from the beginning of the stratification until week 10 is more intensive in cotyledons of seeds subjected to cold stratification $\left(3^{\circ} \mathrm{C}\right)$ than it is the case of warm stratification $\left(15^{\circ} \mathrm{C}\right)$. Throughout the duration of the experiment under the condition of cold stratification the synthesis of protein shows a declining tendency. At $15^{\circ} \mathrm{C}$ from week 6 the synthesis of protein in cotyledons show a growing tendency which between weeks 10 and 11 exceeds the intensity observed at $3^{\circ} \mathrm{C}$.

\section{Transcriptional activity}

Until week 7 the transcription activity changes during cold and warm stratification in a similar manner (Fig. 2). It takes place in phases which are similar to other previously tested metabolic indicators i.e. the content of aminoacids and poly- 


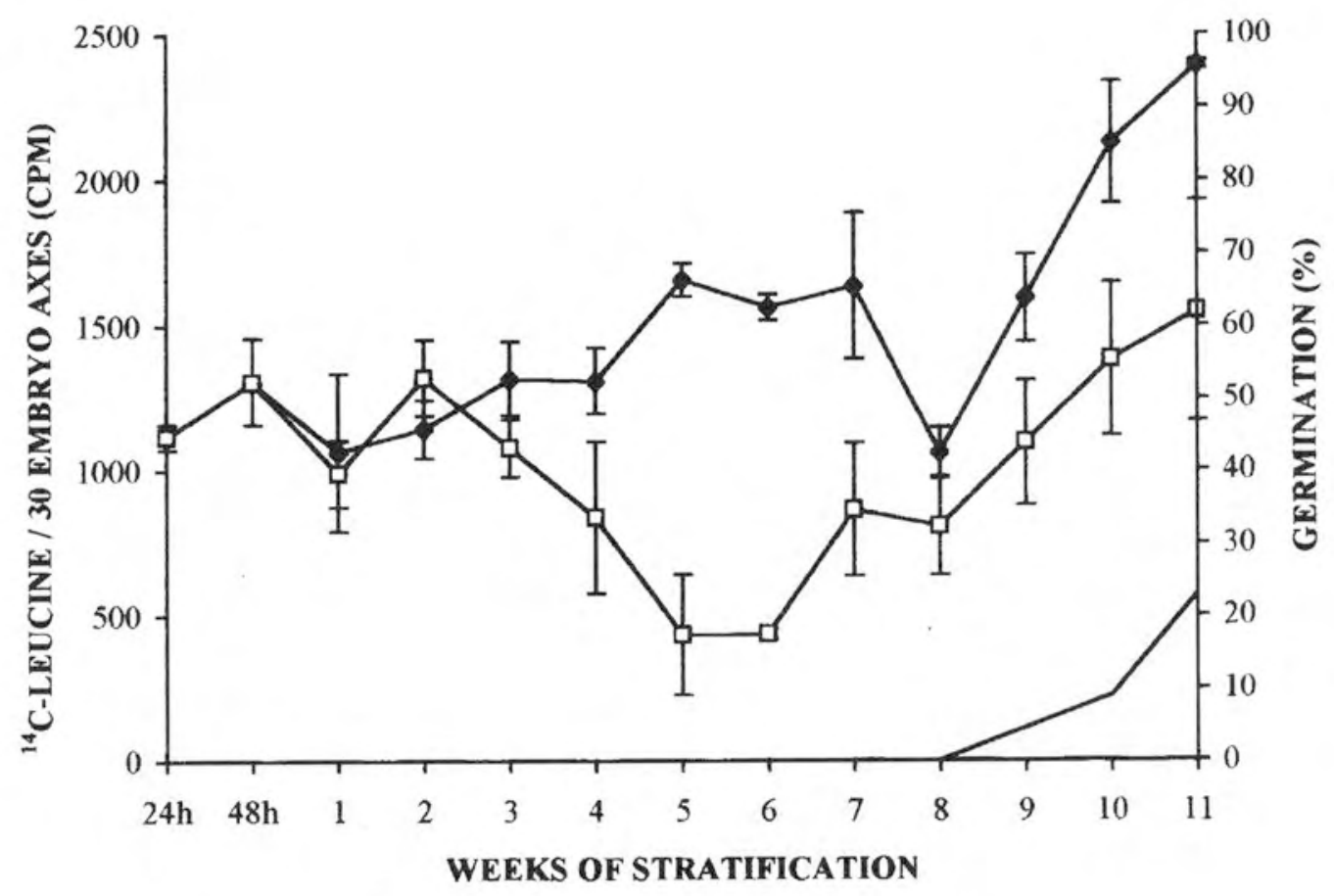

$\rightarrow 3^{\circ} \mathrm{C} \rightarrow-15^{\circ} \mathrm{C} \longrightarrow$ germination

B

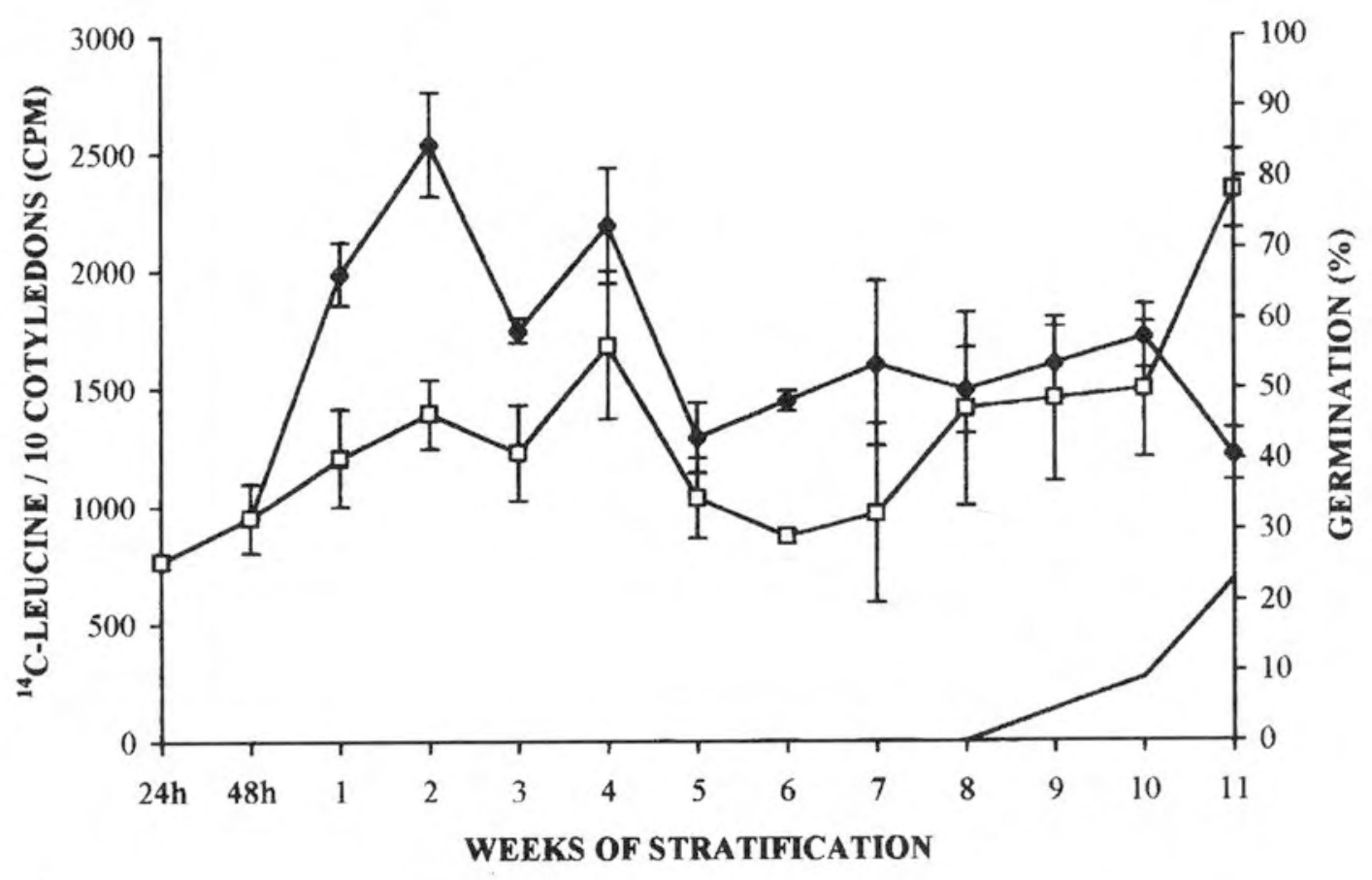

$\rightarrow 3^{\circ} \mathrm{C} \rightarrow-15^{\circ} \mathrm{C} \longrightarrow$ germination

Fig. 1. Protein synthesis activity in embryo axes, as ${ }^{14} \mathrm{C}$-leucine incorporation, $\mathrm{A}$ - embryo axes, $\mathrm{B}$ - cotyledons. 


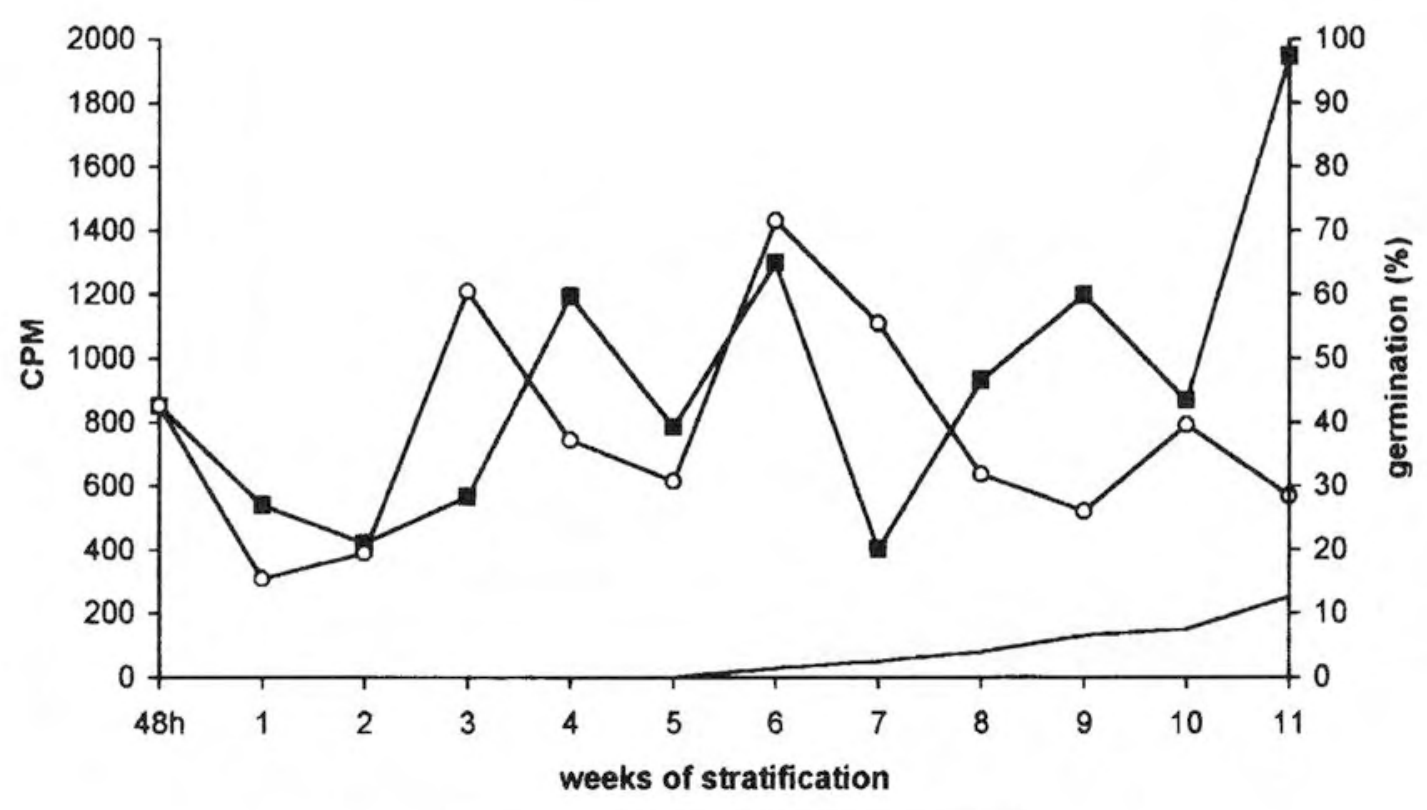

$\rightarrow-3^{\circ} \mathrm{C} \rightarrow-15^{\circ} \mathrm{C} \longrightarrow$ germination

Fig. 2. Transcriptional activity in embryo axes as ${ }^{3} \mathrm{H}$-UTP incorporation into chromatine.

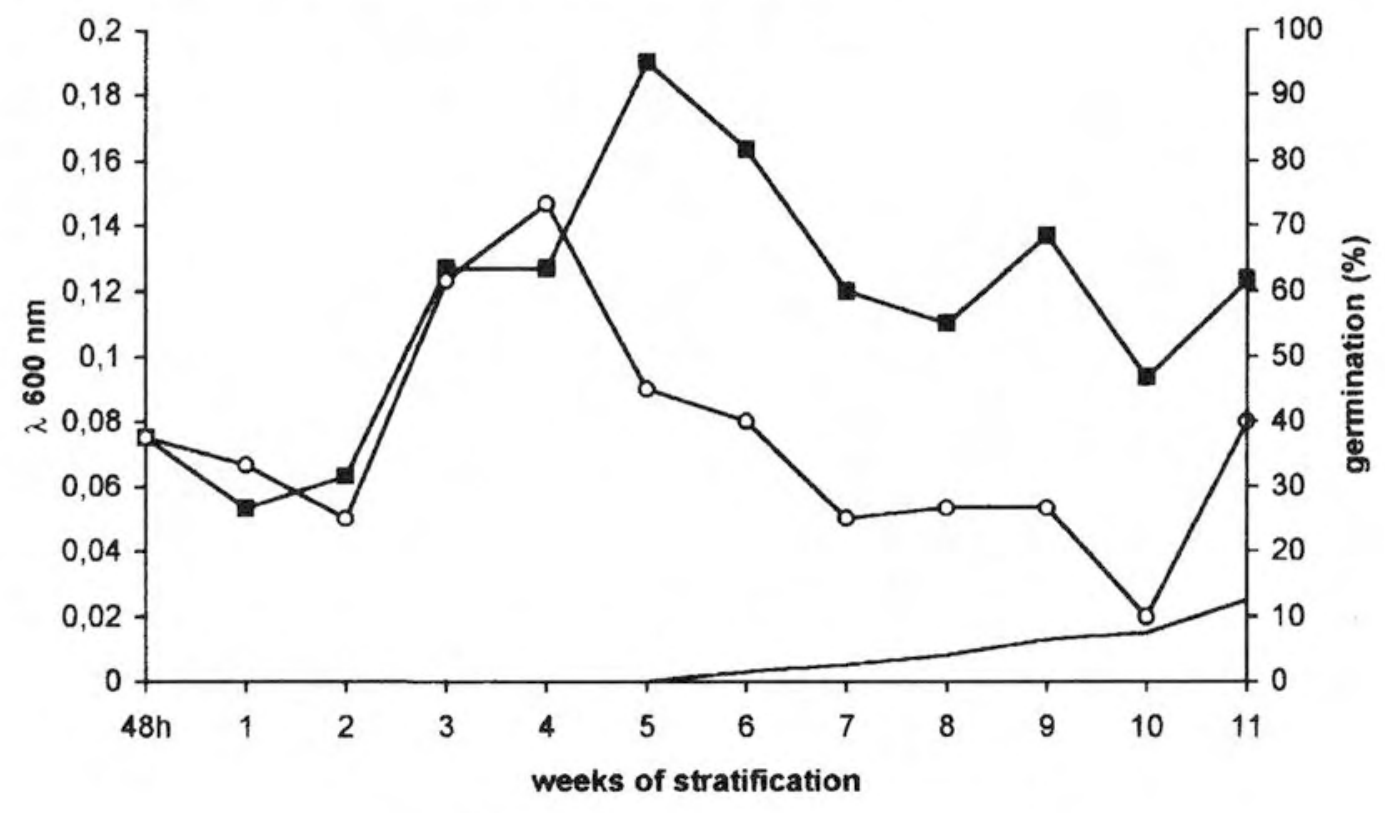

$\rightarrow-3^{\circ} \mathrm{C}-0-15^{\circ} \mathrm{C}-$ germination

Fig. 3. DNA content in chromatine from embryo axes.

amines (Szczotka and Lewandowska 1989) and activity of EF 1 factor (Korcz et al. 1986).

From week 7 (the beginning of germination at $3^{\circ} \mathrm{C}$ ) the transcription activity at $3^{\circ} \mathrm{C}$ increases strongly while it sharply declines at $15^{\circ} \mathrm{C}$.

\section{DNA content}

The content of the DNA in embryo axes of seeds stratified at 3 and $15^{\circ} \mathrm{C}$ is not constant. Until week 2 the level of DNA and the intensity of protein synthesis in both case did not change. From week 2 at both 3 and $15^{\circ} \mathrm{C}$ the content of DNA increases. After week 4 the content of DNA continued growing at $3^{\circ} \mathrm{C}$ but started falling at $15^{\circ} \mathrm{C}$. Until the end of expe- riment the content of DNA at $3^{\circ} \mathrm{C}$ was higher than at $15^{\circ} \mathrm{C}$ (Fig. 3). Changes in DNA content are similar to the changes in protein synthesis and to period changes in transcription activity during last of cold and warm stratification.

\section{Levels and content of individual proteins}

Using the two-dimensional electrophoresis method we achieved a separation of approximately 270 proteins from embryo axes of maple tree (Fig. 4).

After only 48 hours of imbibition the number of protein spots increased in comparision with dry seeds. After week 1 of both warm and cold stratification on gels there appeared a group of several proteins of low molecular weight (14-30 kD) 
of approximately $11 \mathrm{pH}$ (Fig 4d). More new proteins observed at $15^{\circ} \mathrm{C}$ than in $3^{\circ} \mathrm{C}$. In the following weeks we recorded further successive changes in the presence of proteins.

Proteins marked A-H on the photographs are absent in embryo axes of dry seeds even after 48 hours of imbibition. Proteins marked F (approx. $21 \mathrm{kD})$ and $\mathrm{G}(19 \mathrm{kD})$ appear only in weeks 1 and 6 at both temperatures. Protein E (20 kD) appears in week 1 at $15^{\circ} \mathrm{C}$ and in weeks 8 and 10 at both temperatures and also in germinating seeds. In the latter (Fig. 4k) there is no protein marked $\mathrm{H}(15 \mathrm{kD})$, present from week 1 till 10 (Fig. 4c-j) at both temperatures and protein $\mathrm{C}(28 \mathrm{kD})$ present in week 1 at $15^{\circ} \mathrm{C}$, in week 8 at both temperatures and in week 10 (only Fig. $4 \mathrm{i}$ ) at $3^{\circ} \mathrm{C}$. At $15^{\circ} \mathrm{C}$ it appears in much smaller quantities.

The group of proteins marked D $(24 \mathrm{kD})$ appears at both temperatures in week 1 and until week 6 in much higher quantities at $15^{\circ} \mathrm{C}$ (Fig. 4e, f), after ( 8 and 10 week) were more $\mathrm{D}$ in $3^{\circ} \mathrm{C}$ (Fig. $4 \mathrm{~g}, \mathrm{i}$ ). Those proteins are also present in embryo axes of germinated seeds, albeit in smaller quantities.

Proteins A and B (ca $27 \mathrm{kD}$ each) appear in week 8 and 10 (Fig. 4g, i) and in germinated seeds (Fig. 4k). There is more of these proteins at $3^{\circ} \mathrm{C}$ and only traces at $15^{\circ} \mathrm{C}$. At that time (week 10) there is no protein $\mathrm{B}$ at all at $15^{\circ} \mathrm{C}$ (Fig. $4 \mathrm{j}$ ). Protein spots $\mathrm{A}$ and $\mathrm{B}$ introduce a significant difference between both methods of stratification.

Overall, the activity of all metabolic indicators is observed in both cases. However, towards the end of the experiment this activity is much more pronounced at $3^{\circ} \mathrm{C}$ than at $15^{\circ} \mathrm{C}$.

\section{DISCUSION}

Several years ago Tuan and Bonner (1964) proposed that dormancy is associated with represion of the genome and that the genome is unmarked as dormancy is broken. Later Slater and Bryant $(1982,1987)$ suggested that unmarking of the genome does not occur in embryos of Acer platanoides during stratification. They argued that the increased growth potential in the embryo axis caused by stratification is due to an increase in cellular machinery needed for the translation of mRNA i.e. ribosomes.

Results obtained by us showing the dynamics of protein synthesis partly correspond with the results achieved by $\mathrm{Da}-$ vies and Pinfield (1979) i.e. when it comes to embryo axes and cotyledons stratified at $3^{\circ} \mathrm{C}$. At $15^{\circ} \mathrm{C}$ protein synthesis consistently takes place at a lower level both in embryo axis and cotyleons. However, there appears to be a significant similarity in the curves of protein synthesis dynamics at both temperatures.

Our research shows that, just like in the case of other metabolic indicators (Szczotka i Tomaszewska 1979), the process of protein synthesis have a phasic character. The dynamics of transcription activity in embryo axes also occur in stages with a pronounced growth at $3^{\circ} \mathrm{C}$ at the start of germination (7 week) and a corresponding fall at $15^{\circ} \mathrm{C}$ (Fig. 2).

Changes in the level of DNA has been observed under both temperatures variant of conditions (Fig. 3). However, during week 4 of stratification at $15^{\circ} \mathrm{C}$ this level was much lower and its peak preceded the maximum level observed at $3^{\circ} \mathrm{C}$ by a week. This was similar to the dynamics of protein synthesis.

The changes in the activity of the elongation factor observed by us earlier conform to this pattern (Korcz et al. 1986). Those changes are accompanied by the appearance and gradual increase of polysome fraction (Szczotka and Konieczny 1979).
The qualitative changes in protein content in embryo axes occur gradually during imbibition and both warm and cold stratification (Fig. 4). The appearance of new proteins observed just after the first 48 hours of imbibition and later in the first weeks of stratification are, in our opinion, evidence of gradual repression of the genome of dormant seeds. Nevertheless, most of the new proteins are not related to the breaking of dormancy and are the result of imbibition in both temperatures used in the experiments when the temperature of $15^{\circ} \mathrm{C}$ does not lead to seed germination.

It has also been noted that some proteins appear in larger quantities in the embryo axes subjected to stratification at $15^{\circ} \mathrm{C}$.

An important factor contributing to the breaking of dormancy may well be the appearance (in large quantities) of proteins marked $\mathrm{A}$ and $\mathrm{B}$ which takes place in week 8 and 10 (Fig. $4 \mathrm{~g}, \mathrm{i}$ ) of cold stratification and in germinating seeds that are absent or present only in trace amounts in embryo axes stratified at $15^{\circ} \mathrm{C}$ (Fig. $4 \mathrm{~h}, \mathrm{j}$ ).

The dynamics of all the changes in protein synthesis and the qualitative changes investigated earlier or presented in the current paper seem to be similar to the dynamics of biological activity of individual growth regulators in embryo axes which had already been studied at our institut by Tomaszewska (1976). The appearance of large number of new proteins during imbibition and at the start of stratification mirrors the decrease in biological ABA activity in pine seeds (Schneider and Gifford 1994). Our results, however, were similar in both types of experiment $\left(3^{\circ} \mathrm{C}, 15^{\circ} \mathrm{C}\right)$. It points to the lack of direct correlation between the level of $\mathrm{ABA}$ and the breaking of dormancy of maple seeds. In many other species of plant, relation of content and sensitivity to ABA my be different (Hilhorst 1995).

Summarizing our results we found changes occuring:

1. 0-3 weeks (imbibition effects) e.g. Characterized by an increase in protein synthesis in cotyledons but not in the axis. No change in the rate of transcription or DNA content. Changes in 2Ds within $48 \mathrm{~h}$.

2. 3-8 weeks (dormancy-breakage) e.g. Axes protein synthesis and DNA content increases. Presence of protein $\mathrm{C}$ to $\mathrm{F}$.

3. 8-11 weeks (germination) e.g. Axes protein and transcription rates increase. Appearance of proteins A and B. Disappearance of $\mathrm{H}$.

The news proteins which we observed during breaking of dormancy immediate procedes germination. On the other hand if there is no change in conditions required for germination then it can prove difficult to separate which are involved in dormancy-breakage and which are involved in germination.We suggest that the proteins appearing at week 8 could be involved in preparation for germination e.g. reserve mobilizing enzymes or specyfically associated with dormancy-breakage.

According to Janerette (1978) and Pinfield et al. (1987) in maple seeds the cotyledons inhibit the growth of embryo axes. Hance and Bevington (1992) found in the cotyledons of sugar maple (Acer saccharinum) several proteins to which they ascribe the role of inhibitors present in dormant seeds. In the next part of our research, we will be investigating qualitative changes of proteins occuring in cotyledons of Norway maple. 
Fig. 4. Comparison of 2-DE patterns of embryo axes proteins from dry seeds (a), seeds after $48 \mathrm{~h}$ imbibition (b), seeds stratified in $3^{\circ} \mathrm{C}$ and $15^{\circ} \mathrm{C}(\mathrm{c}-\mathrm{j})$ and germinated seeds $(\mathrm{k})$.

Spots marked with $(\mathbf{A})$ are new in comparison with dry seeds. Arrow $(\rightarrow)$ show the differences beetwen $3^{\circ} \mathrm{C}$ and $15^{\circ} \mathrm{C}$ in the same time of stratification.

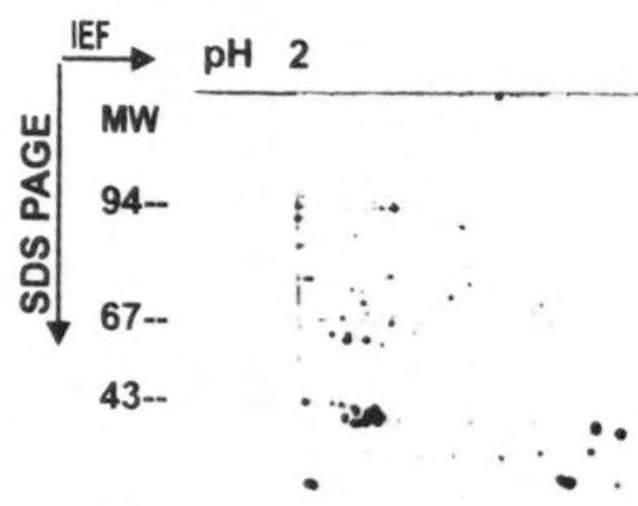

30--

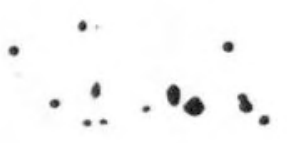

20--

14-

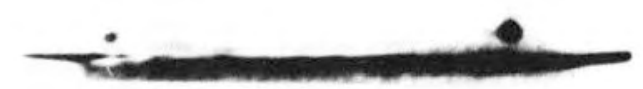

Fig. $4 a$ (dry seeds)
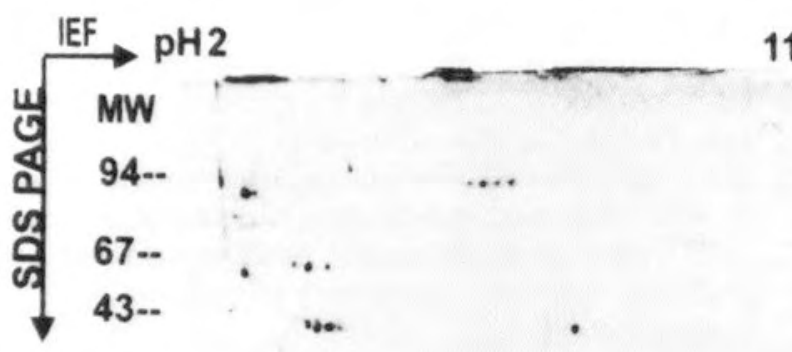

30

20-.

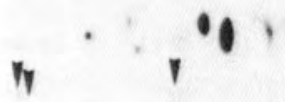

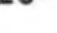

14--
11

11

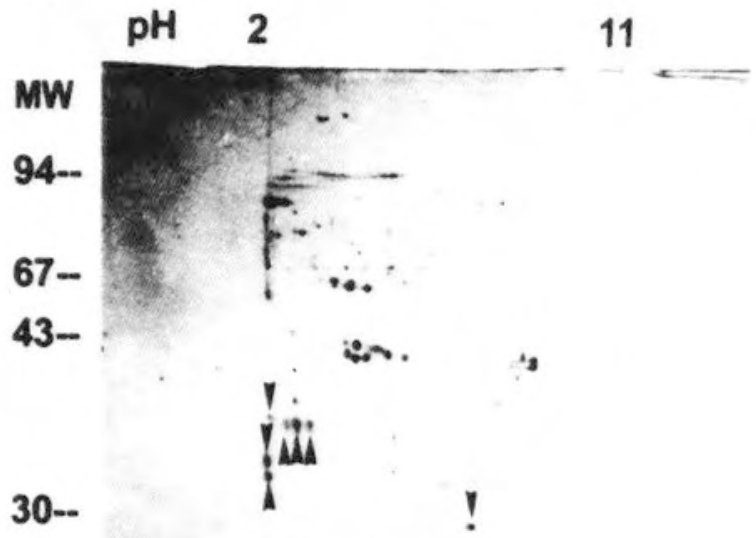

20--

14-

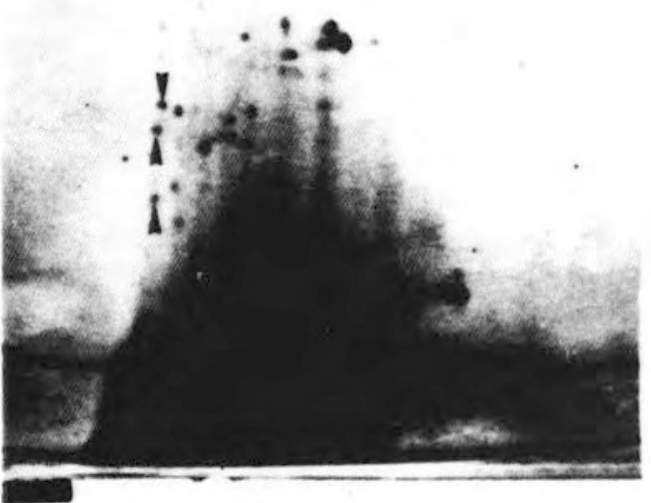

Fig. 4b (48h)

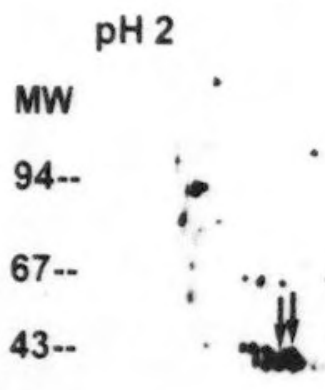

11 


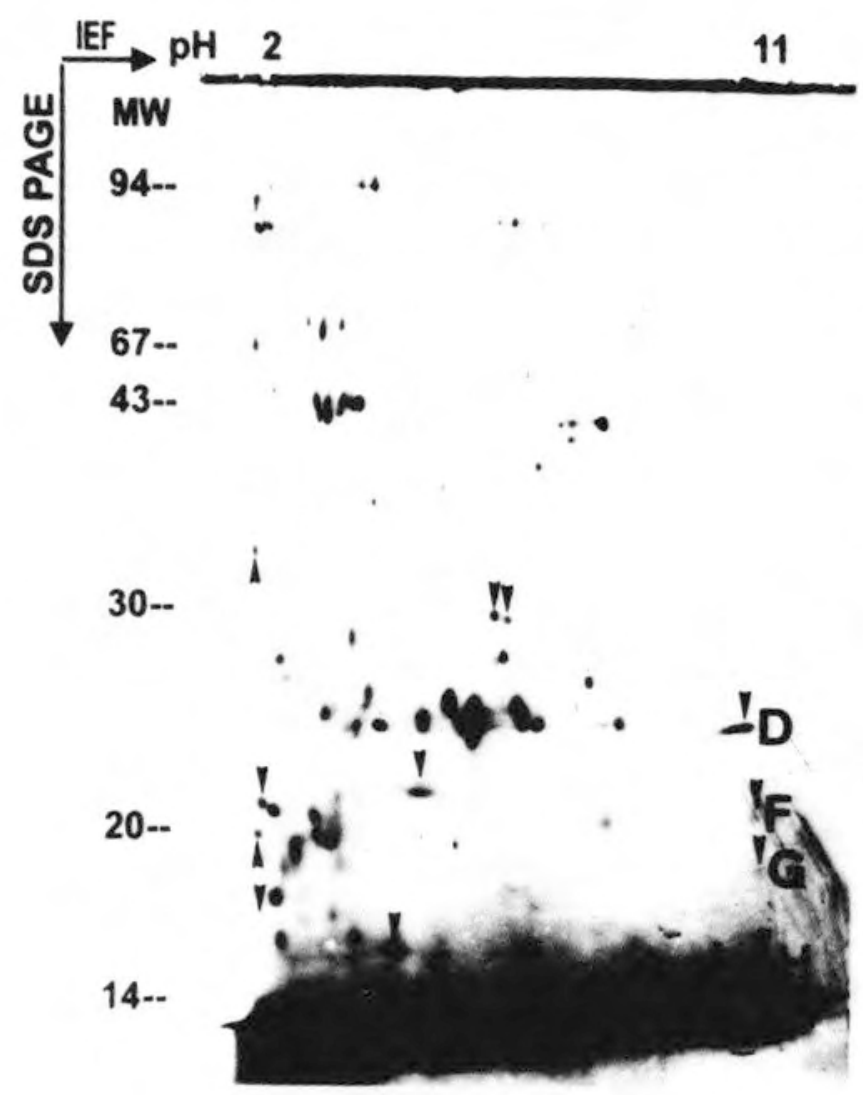

Fig. $4 \mathrm{e}\left(6 \mathrm{w} .3^{\circ} \mathrm{C}\right)$
pH 2

MW

94--

67--

43--

nes,

i

30--

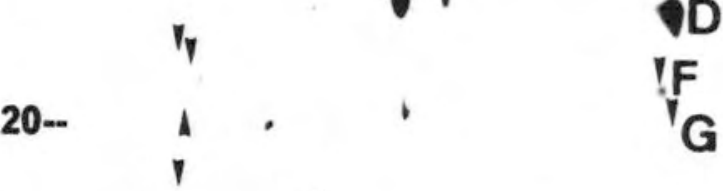

14--

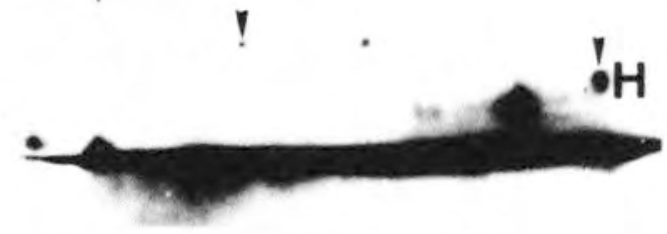

Fig. $4 f\left(6 \mathrm{w} .15^{\circ} \mathrm{C}\right)$

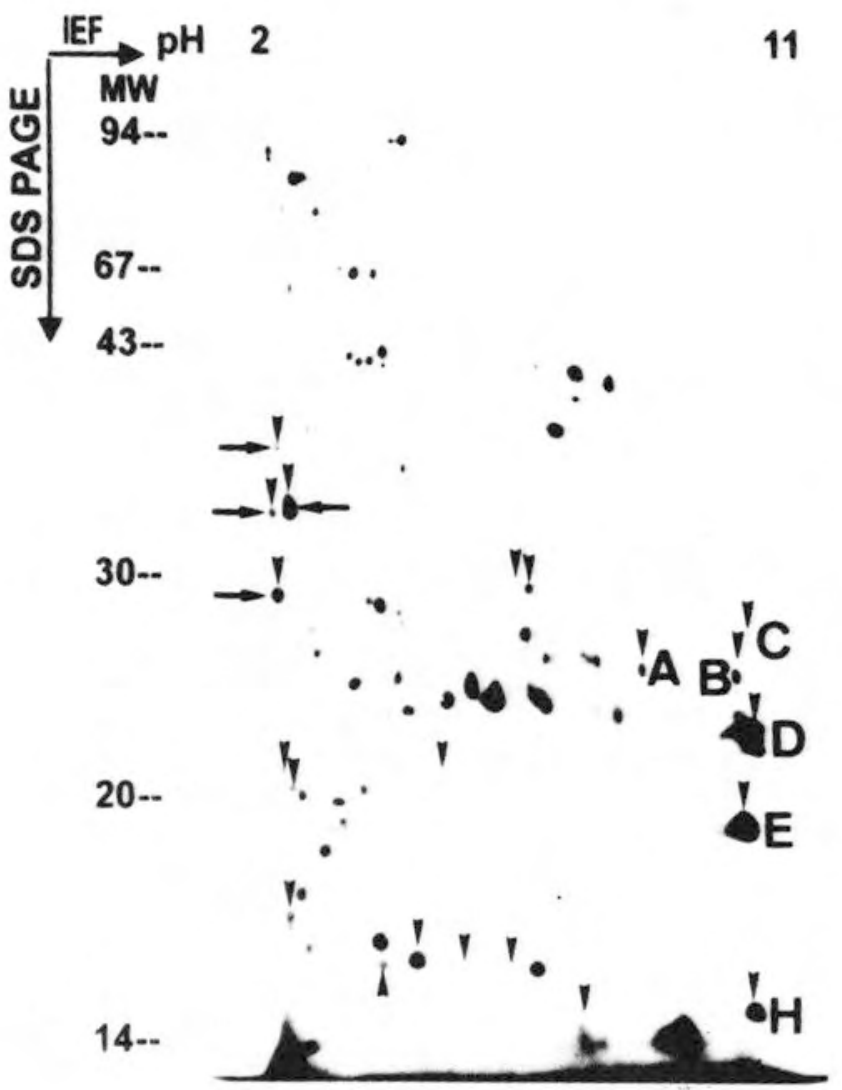

Fig. $4 \mathrm{~g}\left(8 \mathrm{w} .3^{\circ} \mathrm{C}\right)$

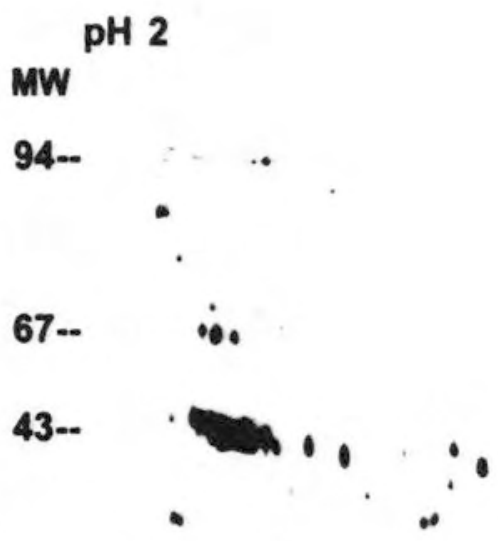

30--

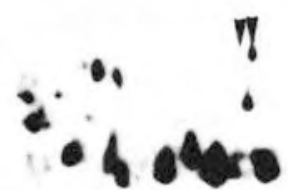

20--

s.

${ }^{\prime} \mathrm{B}^{{ }^{\prime} \mathrm{C}} \mathrm{C}$

QD

'

14-.

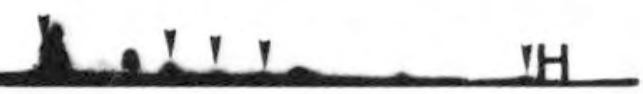

Fig. $4 \mathrm{~h}\left(8 \mathrm{w} .15^{\circ} \mathrm{C}\right)$ 


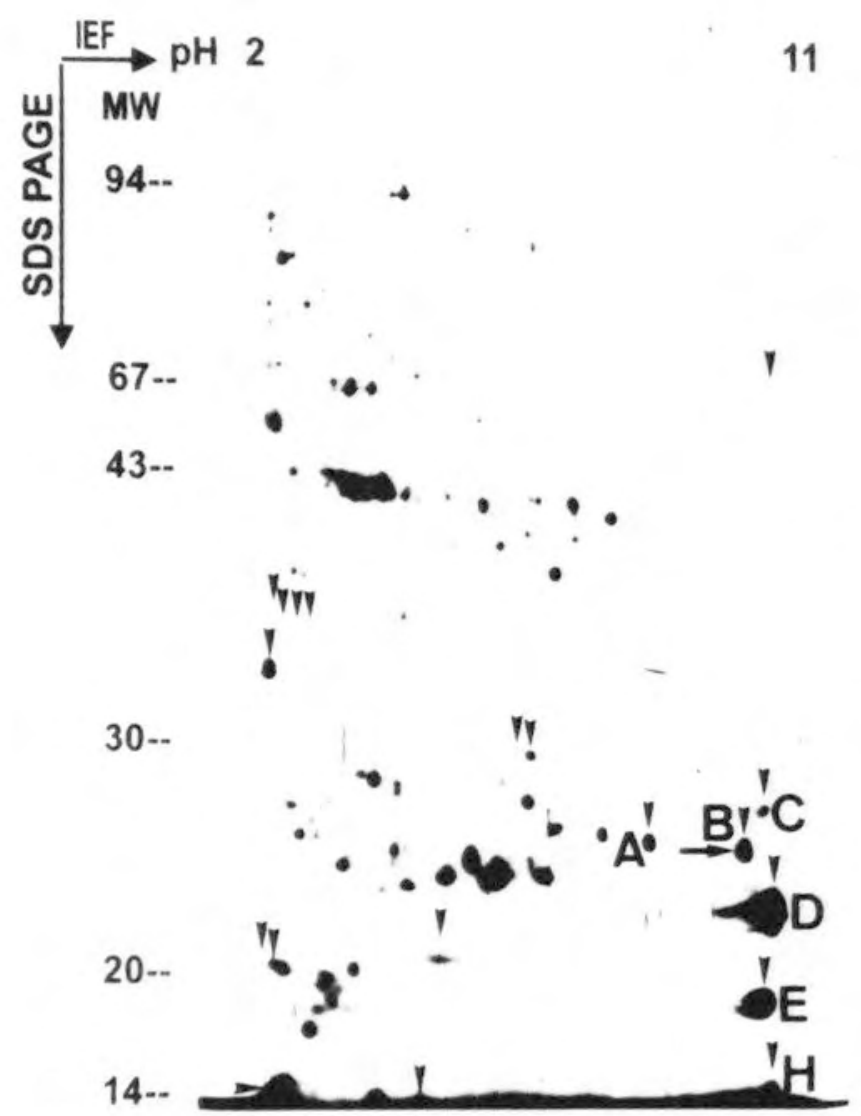

Fig. $4 \mathrm{i}\left(10 \mathrm{w} .3^{\circ} \mathrm{C}\right)$

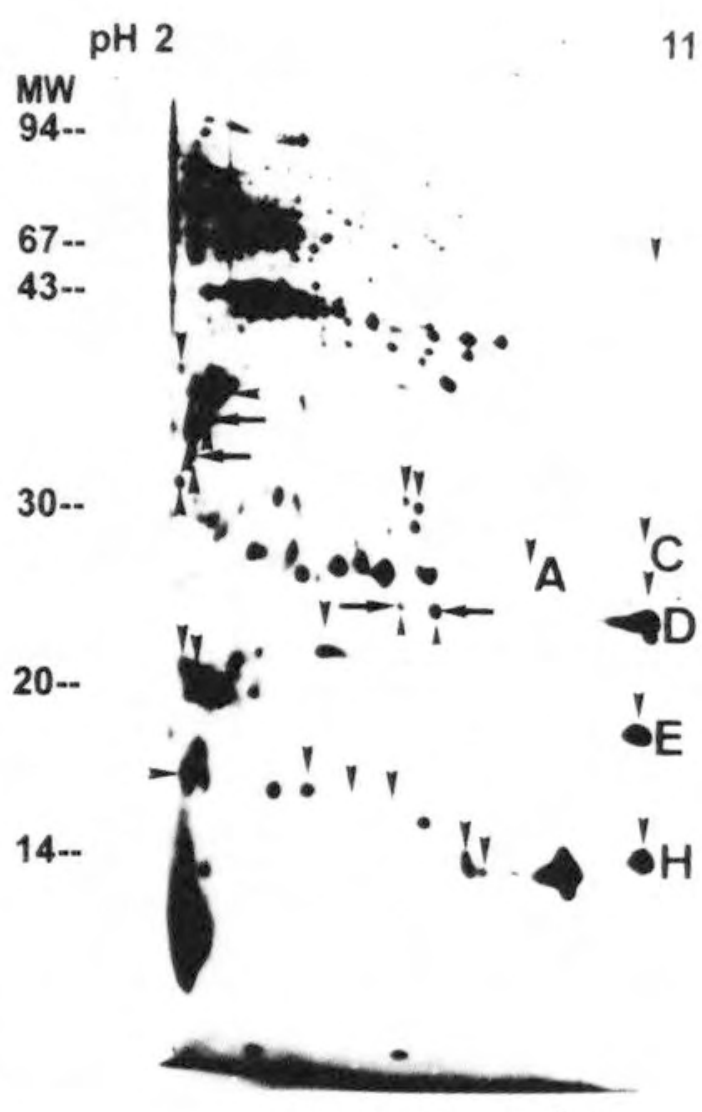

Fig. $4 \mathrm{j}\left(10 \mathrm{w} .15^{\circ} \mathrm{C}\right)$

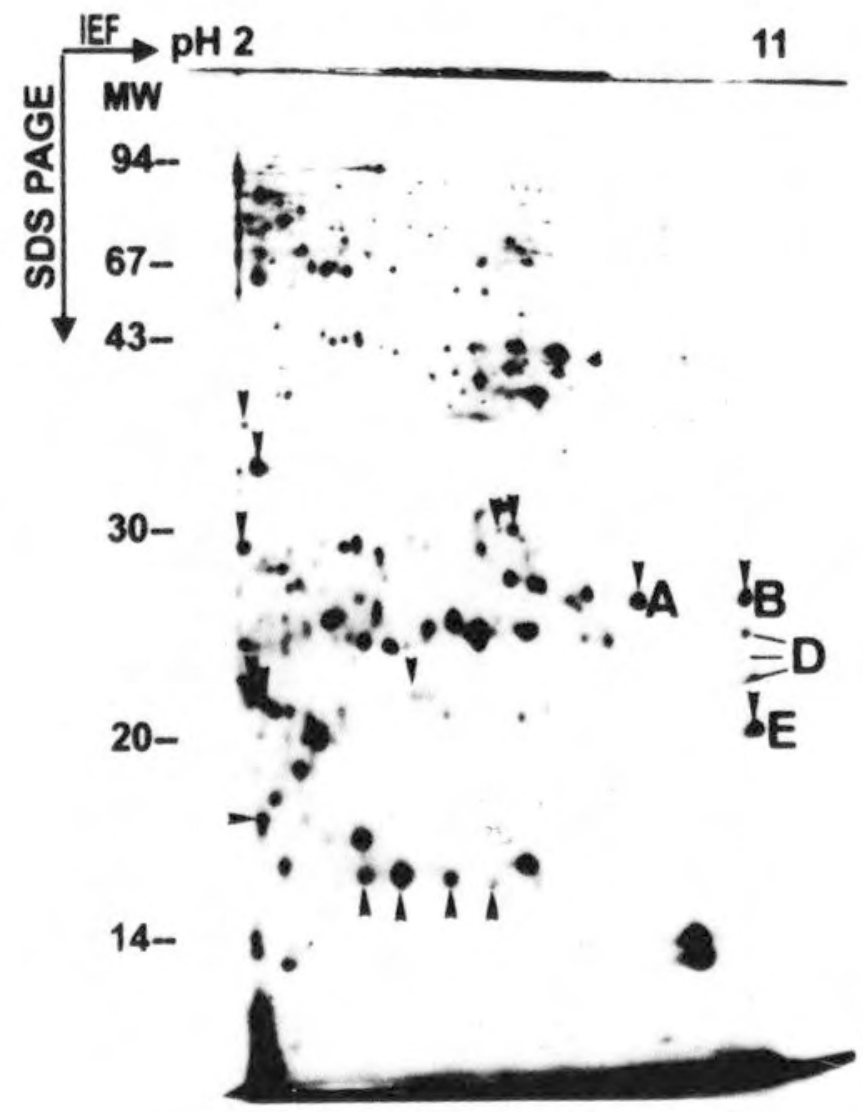

Fig. 4k (germinated seeds) 


\section{ACKNOWLEDGEMENTS}

We are grateful to M.Sc. Magdalena Żymańczyk for technical assistance.

\section{LITERATURE CITED}

BRADFORD M.M., 1976. A rapid of sensitive method for the quantification of microgram quantities of protein utilizing the principle of protein - dye binding. Anal. Biochem. 72: 248-254.

DAVIES H.V., PINFIELD N.J., 1979. RNA and protein synthesis during after-ripening of seeds of Acer platanoides L. Z. Pflanzenphysiol. 92: 85-90.

HANCE B.A., BEVINGTON J.M., 1992. Changes in protein synthesis during stratification and dormancy release in embryos of sugar maple (Acer saccharum). Physiol. Plant. 86: 365-371.

HEUKESHOVEN J., DERNICK R., 1985. Simplified method for silver staining of proteins in polyacrylamide gels and the mechanism of silver staining. Electrophoresis. 6: 103-112.

HILHORST H.W.M., 1995. A critical update on seed dormancy. I. Primary dormancy. Seed Science Research. 5: 61-73.

JANERETTE C.A., 1978. An in vitro study of seeds dormancy in sugar maple. Forest Sci. 24: 43-49.

KHAN A.A., 1982. The physiology and biochemistry of seeds development, dormancy and germination. Elsevier Biomedical Press. Amsterdam. New York. Oxford. pp. 176-190.

KLOSE J., 1983. IN: TSCHESCHE H. (Ed.). Modern methods in protein chemistry. Walter de Gruyter Verlag. 49-78.

KORCZ A., SZCZOTKA Z., TWARDOWSKI T., 1986. Elongation factor 1 in Norway maple seeds during the Breaking of Dormancy. J. Plant Physiol. 123: 317-326.

LAEMMLI U.K., 1970. Cleavage of structual proteins during the assembly of the head of bacteriophage T4. Nature. 227: 680-685.
PINFIELD N.J., STUTCHBURY P.A., BAZAID S.M., 1987. Seed dormancy in Acer: Is there a common mechanism for all Acer species and what part is played in it by abscisic acid. Physiol. Plant. 71: 365-371.

ROSS J.D., BRADBEER J.W., 1971. Studies in seed dormancy. Planta. 100: 288-302.

SCHNEIDER J., 1983. Udział cytokinin w regulacji aktywności transkrypcyjnej. Wydawnictwo Naukowe UAM. Poznań. Poland. pp. 27-29.

SCHNEIDER W.L., GIFFORD D.J., 1994. Loblolly pine seed dormancy. I. The relationship between protein synthesis and the loss of dormancy. Physiol. Plant. 90: 246-252.

SLATER R.J., BRYANT J.A., 1982. RNA metabolism during breakage of seed dormancy by low temperature treatment of fruits of Acer platanoides (Norway maple). Ann. Bot. 50: 141-149.

SLATER R.J., BRYANT J.A., 1987. RNA polymerase activity during breakage of seed dormancy by low temperature treatment of fruits of Acer platanoides (Norway maple). J. Exp. Bot. 38: 1026-1032.

SZCZOTKA Z., 1975. Changes i the intensity of protein synthesis in the embryo axes of nothern red oak (Quercus borealis Michx.) and English oak (Quercus robur L.) during storage under controlled condition. Arboretum Kórnickie. 20: 291-297.

SZCZOTKA Z., KONIECZNY A., 1979. Polysome fraction in the seeds of Norway maple (Acer platanoides L.) during the breaking of dormancy. Arboretum Kórnickie. XXIV: 147-152.

SZCZOTKA Z., LEWANDOWSKA U., 1989. Polyamines in dormancy breaking of tree seeds. Ann. Sci. For., 46 supl.: 95-97. Forest Tree Physiology. E. Dreyer et al. eds. Elsevier/INRA.

SZCZOTKA Z., TOMASZEWSKA E., 1979. Some metabolic processes accompanying dormancy breaking in the seeds of Norway maple (Acer platanoides L.). Arboretum Kórnickie. XXIV: 137-146.

TOMASZEWSKA E., 1976. Growth regulators in Norway maple (Acer platanoides L.) seeds. Arboretum Kórnickie. XXI: 97-312.

TUAN D.Y.H., BONNER J., 1964. Dormancy associated with repression of genetic activity. Plant Physiol. 39: 768-772.

\section{ZMIANY JAKOŚCIOWE W DYNAMICE I SYNTEZIE BIAŁEK PODCZAS CHŁODNEJ I CIEPŁEJ STRATYFIKACJI NASION KLONU ZWYCZAJNEGO (ACER PLATANOIDES L.)}

\section{STRESZCZENIE}

Synteza białek w osiach zarodkowych i liścieniach klonu zwyczajnego (Acer platanoides) była badana w nasionach stratyfikowanych w 3 i $15^{\circ} \mathrm{C}$.

Nasiona stratyfikowane w $3{ }^{\circ} \mathrm{C}$ rozpoczynają kiełkowanie od 9. tygodnia, a stratyfikowane $w 15^{\circ} \mathrm{C}$ nie kiełkują do końca doświadczenia. Zmiany poziomu syntezy białka mają charakter fazowy w obu temperaturach. Zmiany te wykazują tendencję rosnącą w osiach zarodkowych szczególnie w $3^{\circ} \mathrm{C}$, a w liścieniach $\left(3^{\circ} \mathrm{C}\right)$ malejącą.

Generalnie aktywność syntezy białka jest wyższa w $3^{\circ} \mathrm{C}$, podobnie jak poziom DNA.

W czasie pęcznienia, ciepłej $\mathrm{i}$ chłodnej stratyfikacji w osiach zarodkowych pojawiają się liczne nowe białka. Sądzimy, że dwa z nich określone jako A i B mogą być związane z ustępowaniem spoczynku w $3^{\circ} \mathrm{C}$. Te białka w nasionach stratyfikowanych w $15^{\circ} \mathrm{C}$ występują śladowo lub wcale nie występują.

SŁOWA KLUCZOWE: Acer platanoides, białka, DNA, nasiona, spoczynek. 